\title{
COLLECTIVE MENTALITIES IN THE SYSTEM OF CULTURAL DETERMINANTS OF SOCIAL COMPETENCE
}

\author{
OLENA VARETSKA
}

\begin{abstract}
The article substantiates the importance of the development of social competence in the process of globalization. It outlines the author's view on the influence of collective mentalities in the system of socio-cultural determinants, researches the opinions of scholars on the essence of mentality, individual and group mentality, nation and ethnos mentality. It covers the features of ethnic Ukrainians, their inherent trait enabling to consolidate around the national idea.

Keywords: social competence, personality, determinant, system, mentality, collective mentalities, ethnomentality, national mentality.
\end{abstract}

\section{INTRODUCTION}

The process of Ukrainian integration into European Union suggests socio-economic, ethnological, political, ideological, and spiritual search of optimal models for transformations and development of Ukrainian society and the national revival of the country particularly in conditions of Russian military aggression. It is of utmost importance to rethink the clashes of deep-rooted views, contradictions and problems of self-awareness of the Ukrainian nation, its values, normative and mental-psychological principles. These social challenges affect personal development, social competence, putting forward new requirements for the latter. It should be noted that the issues of national mentality and collective mentalities should be studied at interdisciplinary level due to the complexity and diversity of their manifestation that involve traditional and innovative aspects. They are reflected in unique national and social development, ways of thinking and actions that are of particular importance for the socialization of personality, social competence. Given that this competence is an operational concept with the historical period, it seems quite reasonable to develop behavioural scenarios that reflect new social reality, open up new social perspectives of knowledge of the world and humanity. Moreover, a personality combines social and individual traits, and therefore his or her value orientations, social and other competences in the process of activity change simultaneously with the society in which he or she lives according to the historical period under the influence of the system of socio-cultural determinants, with collective mentalities as their components. 


\section{RESUlTS}

Covering the topic, we consider reasonable to ground our research on the definition of the concept of "social competence", presented as follows: a holistic socio-pedagogical phenomenon, which ensures systemic nature of social responsibility, professional development and self-development of a person, his or her creative potential, high level of quality of work and social maturity in accordance with new requirements and needs of the society. This definition is based on a combination of socially significant qualities and items, social and emotional intelligence, social values, the ability to establish social and professional relationships, social interaction in real life, the ability to influence the process of life at a certain level of competence acquired [38, p. 123]. It is obvious that the described process takes place under the influence of certain determinants.

It is noteworthy that the concept "determinant" (from Latin - determinans, determinantis -et that defines, restricts) is applied in different aspects and fields of science (philosophy, economics, religion, etc.) with similar meaning in English, German, and Greek. It is defined as a factor that determines the phenomenon; reason, premise, component (constituent, element), etc., but at the same time different shades of meaning are important. G. Gurvitch wisely presents it as a "universal factor" [10, p. 137, 138.]. The determinant fills the identified realis with the content in particular place of social space, and shapes the functional orientation of the environment. In the article, the concept "determinant" indicates the sphere of existence, condition, factor, which determines the essence of the process. Such conditions, factors, move and influence directly natural processes, disasters, living conditions; indirectly, for example, due to historical, geographical environment of races and nationalities; remotely in space, time, and thus contribute to or hinder the development of social competence of an individual. In turn, "sociocultural character" is the basic category of the social world (super organic world), which connects personality, his or her culture, interaction (P. Sorokin) [34], it is understood as a combination of culture and society, as something that is conditioned by social and cultural reasons [29].

To deal with the issue of collective mentalities, the concept "sociocultural" is considered of utmost importance. It is defined in different fields of science as interaction between individuals and their groups in all spheres of their life. Note that a significant part of scholars emphasizes on these very aspects defining the concept of "social competence" [38, p. 91, 97]. Social competence is built on parallelism, unity of certain cultural phenomena, norms, values (internalized by these groups and individuals) and certain community, social constructs / structures in which these cultural phenomena are manifested [32].

In turn, culture as a set of values and norms with socio-cultural contradictions, which arise at all times, is the plane of reproductive human activity $[14 ; 21 ; 35 ; 36]$. This is because they are subjected to different laws and internal contradictions in the process of reproductive activity; and the effectiveness of this reproductive activity is the consequence of changes in social relations [14;38]. Culture, however, is an ethnically and mentally specific program, a regularity of life-formation, a way of being, functioning in the form of community life. It is a reality in which the past, present, future are presented in integrity [22, p. 2].

Given that all factors affecting the development or functioning of a society are mediated by such social and cultural achievements as social psychology, socio-cultural character is a determinant of social development. In this case, the prevailing number of factors (active, random) in society (metabiological, specific ways of activity) is phenomena of culture [18, p. 136; 21; 36]. Socio-cultural determinants also provide the opportunity to carry out a systematic analysis of social phenomena in a multifactorial dimension, since several of them can exist together or change their influence on the quality of organization of social constructions. That is why the socio-cultural determinants of social development and the development of social competence at different levels (mega-, macro-, meso-, micro- levels) require a combination of history, culture and social practice to be involved.

Summarizing the abovementioned, outlining the system of socio-cultural determinants [38, p. 165], let us dwell on the determinant of collective mentalities - states, thoughts, collective experiences. It is the very position that manifests itself in the characterization of mentality in post-Soviet cultural and 
philosophical literature $[17 ; 23]$ as a set of "representations of people of particular historical time, geographic territory and social environment, a special psychological type of a particular social formation that affects historical and social processes" [23, p. 49].

The problem of mentality in its various aspects has always been in the focus of attention of foreign and Ukrainian scholars.

It is noteworthy that the concept of "mentality" comes from the Latin "mens" and is translated as mind, thinking, way of thinking, mental composition. It is polysemantic and is used to refer to the deep level of human thinking that is not limited to the conscious sphere and reaches the unconscious (according to many scholars, it was probably introduced into academic usage by R. Emerson in 1856) $[3 ; 4]$.

According to J. Gurvitch (1894-1965), mentality is a multifaceted phenomenon, a reflection of "a drama that is weaker or more agitated and spontaneously guided by social element" [11, p. 156], and "an integral part of social reality, which permeates the latter and is manifested in various forms" [10, p. 151]. These forms are: mental states (characteristic features, memory of the people, suffering and satisfaction, uncertain attempts and conscious efforts directed at practical realization of historical knowledge); generally accepted views (at all times, uncertain and fuzzy). The scholar refers to mentalities "three manifestations of life", that is, variations of mentality, or mental actions (intuitive and emotional or rationally balanced and purposeful). They "materialize the mentality with respect to the person, world, and social environment to which the mentality is adjusted and immanent" [10, p. 151].

Expanding on the maximal efficiency of the mental in society, J. Gurvitch proves that the mental is in balance with the social. At the same time, the states of mentality (états mentaux) testify the smallest degree, and commonly accepted views (opinions) - the sustained degree of immanence of the mental and social balance. In turn, mental actions (actes mentaux) show the maximum degree of immanence of both. The essence of their immanence is clarified by a scholar through a figurative comparison with models, rules, signals, signs, social roles, modes of action, symbols, ideas, values, and the whole heritage of civilization, which "reciprocally accumulate" and equally strongly induce mental and social to life. The scholar imagined "social and mental in the form of two circles, which overlap having one common sector, though other sectors are different and do not overlap" [4, p. 18; 42, p. 156].

Similar opinion is expressed by S. Grabovsky, who noted that mentality "covers the layers of the conscious and the unconscious, the layers of so-called spiritual traditions, common for the integrity of people living on a particular territory, communicate with specific languages and call themselves by the name - ethnic, national, sub-ethnic" [13].

According to the arguments of the Russian scholar A. Gurvich, mentality is a generalized way of perceiving the world, a way to feel and think, characteristic of people of a particular era, the property of traditional ethnic consciousness to reflect (and express their own behaviour) a definite ethnic picture of the world in a special way [14;15], which is created by human perceptions of the world, formed on the basis of well-defined cultural and value dominant. We completely agree with the statement of I. Pidlasyi [26, p. 86] on the individuality seen as the combination of individual development, hereditary, and environmental influence.

In this context, in the focus of our attention are the works of Western scholars such as F. Dretske [5] or J. A. Fodor [6]. They are convinced that generalization people use in everyday life to predict and explain each other's behaviour are apt and therefore are referred to as the term "popular psychology". In addition, apparently - they correspond to psychic and social, because personal and spiritual values, in which people believe, their desires and doubts, fears are seen as corrected indicator of actions of an individual in a certain situation. Therefore, according to D. Pitt, people have no other way of understanding the behaviour of others than assigning similar states and using certain generalizations [27].

However, V. Kriachko states that a greater number of scholars ignore the fact that the very social environment can be also characterised as dysfunctional, and instable and variable. This refers to the understanding of the manifestations (through mentality) of various signs of social problem, non- 
functions and sociopathy of diverse genesis and social-sub-system dimension [17, p. 5]. In the process of socialization (given the understanding of this concept in the context of the development of social competence - the note is ours) an individual appropriates norms, values, views that are outwardly dictated by parents, educators, and social group [38, p. 157]; the properties of the social system, and through them - mental prescriptions, which are close to social norms or are associated with manifestations of certain violations of this process [17, p. 5].

In addition, according to $\mathrm{Yu}$. Romanenko, socialization is a process of sense production and exchange that occurs in the relations of a person, social system, subsystems, various organizations, and has as a fundamental intention to achieve the complementarity of macro-identity of the social system and the identity of the basic person - the normative social type on the basis of the achievement of the socioecological balance in the structuring of space and time in the system and personal dimensions. Socialization is mediated by cultural universals which contribute to the establishment of upper threshold of deviance (maximum possible deviations of personal behaviour from the normative standards and expectations which set the social micro performance, that is, the minimum acceptable for the social system scenario-matrix of the deployment of the vital activity of an individual) [30, p. 5]. At the same time, most scholars recognize the mentality as a group phenomenon, a hidden, deep, nonreflected part of the public consciousness; the result of the unconscious process of unification of the ways of worldview, attitude, worldview and reproduction in identical behaviour. In particular, philosophical encyclopaedic dictionaries interpret the notion of "mentality" (from the late Lutheran mentis - mental) as a way of thinking, the general spiritual attitude of man, a group of people [8; 9]. In turn, V. Andrushchenko defines it implying a multifaceted conception for "seeking a deep level of human thought, the content of which is not limited to conscious positioning, including the sphere of the unconscious" [1, p. 443].

However, V. Kriachko, defining mentality phenomenon associated with reason, thinking, does not identify it with social consciousness. In his view, the mentality characterizes only the specifics of such consciousness in comparison with social consciousness, as a rule, large groups of people (ethnic group, nation or social stratum) [17, p. 13]. Moreover, mentality is a common "social equipment", which provides a specific perception of its members and "constitutes the behaviour of individuals, social groups, macro society in the objective process of the dynamics of society" [17, p. 19].

That is why, alongside with the mentality of a particular person (the individual, the mental profile that determines the life scenario), which is reflected in her or his personal values and stereotypes, in assessing the world around, the place in this world, in response to public opinion and the laws of morality, group civilization, ethnic mentality, and national mentality are considered. In particular, the term "group (collective) mentality" with reference to legal solidarity of people - primary subjects of legal consciousness was used by E. Durkheim. Taking into account the abovementioned, L. Sandyuk reasonably defines mentality as "a profound level of collective and individual conscious individual or social group for the promotion of a certain type of perception, thinking or action" [31, p. 26].

In the context of our research, the definition of mentality given by O. Shmorhun is important. He defines mentality as a determinant with the content of the defining feature, which provides adaptation of members of society to changes in socio-economic, spiritual and cultural conditions [33, p. 47], maintains the sustainability of the very existence of the society itself. Hence it turns out that the mental profile of the social system combines the algorithms of socialization of individuals, the mechanisms of acquisition, expansion of their life experience through the process of knowledge of objective reality, it reproduces accumulated historical information about the development of society [17, p. 19], and, as we see it, the development of social competence.

Taking into account that the mental profile at all levels (from the ideological, theoretical to the common-practical and unconscious) is an essential system of historical development, V. Kriachko $[17$, p. 19] emphasizes not only the importance of the set of mental characteristics of a particular society, but also the levels and specificity of their manifestation (mental properties of macro communities, stereotypes of behaviour of members of a specific society, standardized social behavioural forms, inherited from the past as traditions, customs of society, existing in concrete community in the form of 
knowledge and beliefs. Consequently, the essence of the mentality of the society has a manifestation in the system of its purpose forming.

In this context, we can talk about two related types of mentality: national and ethnic. Therefore, the first mentality (according to S. Honcharenko) is a specific way of perceiving (interpreting) the inner world and external circumstances by a nation. National mentality is cultivated under the influence of cultural, historical, and geopolitical factors. The mentality of the nation is a holistic spiritual entity (it has no internal distinction as an economic, political, moral, etc.), "the spirit of the people", and permeates all spheres of human activity. It retains the code of the nation and manifests itself in the national character, identity of the ethnic group, various components of its culture [12, p. 276]. A similar opinion is expressed by S. Krymskyi regarding the specificity of the perception and interpretation of the world in the spiritual life of the people, nations, social groups, which are determined by certain socio-cultural phenomena [16, p. 369].

According to S. Honcharenko, the mentality of the Ukrainian people is characterized by freedom, individualism, aspiration for social equality, democracy, spiritual aristocracy, optimism, philosophy of the soul, deep religiosity, mercy, sincerity and sincere generosity, hard work [12, p. 276]. Note that the characteristics of emotionality of Ukrainians (according to O. Vyshnevsky) and features of mentality have much in common [40].

Another ethnic mentality is reasonably considered to be an important component of the ethno genesis of any people, a form of spiritual and cultural self-expression of members of ethnic communities in ethno-differentiating traits (they have roots in the peculiarities of cultural and economic activity, in mental composition, behaviour, and ethno-cultural constructs). In addition, ethnic mentality is seen as a way of perceiving the surrounding world and the peculiarities of responding to its phenomena, depending on ethnic factors, norms and values, mood, form of relationships, etc. [42, p. 205].

It is well known that the traditional spiritual ideals of every people are based on the spiritual guidelines of the people, which is extremely important in the development of the state. This conclusion can be found, among others, in J. Gasfield [in 2, p.11]. It is quite reasonable to consider O. Budnyk $[2$, p. 11], who states that all people as ethnic groups are extremely sensitive to their own origins and values. Of course, every ethnic group is marked by positive and negative individual national qualities of nature. However, it is not possible to equalize, to generalize the perception of all representatives of a certain people in view of non-acceptance of their own generalization with the whole ethnic group or people by each individual. This view is confirmed in the statement of G. Lebon on the selectively taken thousands of Frenchmen, thousands of Englishmen and thousands of Chinese who are naturally different from each other, but are characterized by common traits they inherited. On this basis, one can outline the ideal type of Frenchman, Englishman or Chinese [20, p. 22].

That is why it can be argued that ethnic Ukrainians are characterized by respect, "land worshiping", eternal aspiration to private property, respect for parents, excessive caution, complacency, hard work. This is confirmed by numerous ethnographic studies, works of Ukrainian literature, although there are other common thoughts on hardworking Ukrainians, in particular expressed by A. Palamar [25, p. 64, 67]. However, according to O. Budnyk and I. Pidlasyi, Ukrainians, as a great nation, should do their best to prosper due to their hard work [2, p. 15; 28, p. 10]. In addition, one cannot but mention the characteristics of Ukrainians as a tendency to individualism (the desire for independence in economic activity), petty ambition, egocentrism - "closure" in their own "Ego", neglecting public interests up to a complete self-isolation, which has a manifestation of social pessimism, extreme careerism, indifference to the personal goals and sometimes passive attitude to achieving their goals, which, can be caused, to our mind, by a long-term statelessness. Similar ideas are expressed by O. Budnyk [2, p. 17]. We can also add that the specified characteristics are most expressed during periods of disasters.

In addition, study and interpretation of the peculiarities of the semantic space of various groups of respondents, in particular performed by O. Frolova, confirmed the fact that the process of the communicative field structuring is influenced by the national-ethnic group [7, p. 175]. However, the 
events of recent years and of today convincingly testify to the fact that such people can "unexpectedly see the light" in certain circumstances, receive respect and support of most countries of the world as fighters for democracy, freedom, who seek honest and free economic activity in their country. L. Kuchma's words are quoted by N. Yakupova with reference to the events of the Orange Revolution. Today there are more convincing arguments in favour of this idea: events of the end of 2013 beginning of 2014 - the dignity revolution, for which more than a hundred citizens of Ukraine laid their lives, as well as the war against the Russian aggressor. It is well-known that Ukraine is a multinational country, where every fourth is not an ethnic Ukrainian. Referring to Z. Freud, the author comes to a reasonable conclusion. The idea behind is that there is no full equality between nations, although within the boundaries of an ethnic group and on the basis of ethnic separation there will always be wars, since every person has a natural aggression to protect himself and his relatives from enemies [41].

In this context, the statement by L. Orban-Lembryck about the situation of the "contact hypothesis" seems quite right. According to it the uncompromised business interaction and communication between representatives of different ethnic groups reduce egocentrism and stereotypes of evaluation, sometimes it can go even to the destruction of interethnic stereotypes. At the same time, the effect of mutual disagreement disappears only on condition of observance of clear requirements, among which are the following: recognition of the undoubted equality of parties, creating an environment of openness and trust in communication, respect for traditional norms, way of life, etc. [24, p. 4]. Consequently, the above-mentioned events naturally united the citizens of Ukraine (regardless of nationality) with the common idea of European development and protection of their own country, but certain part of the society was rejected. It should be noted that the objectives of our article do not suggest the analysis of these events. However, we should emphasize that besides the use of "organizational weapons" (application of the system of organizational, propaganda, psychological, informational influences against the target state, which force it to move in the necessary for the opposite side direction [22]), the influence of media attacks, information from the Russian mass media, psychological pressure on the population, first of all in the east of Ukraine, historic distinction of Ukrainians contributed to the complication of the situation. G. Filipchuk proved this idea in his research. The scholar noted that Ukrainians as a nation always lacked the commonality of historical destiny. For centuries Transcarpathia and Volyn, Galicia and Crimea, Bukovyna and the Dnieper region lacked integral communities [37, p. 229]. Hence, the people who were forcibly divided with other states' borders did not have an opportunity to develop their national ideal of humanism, democracy, and citizenship in the context of their own history, traditions, culture, and morality [37, p. 229].

For the first time in years of independence of the Ukrainian state, a national idea emerged. It should become a world-view orientation in the education system, in the field of development of social competence. Today, the national dignity of Ukrainian citizens is difficult to generate, when each ethnic community is guided by its own behaviour, rules and regulations, manifested in morals, customs, experience in raising children, managing economy, trying to create positive image of the people, "one should behave in such a way as to present a decent image of nation" [39, p. 49].

In the context of the abovementioned, we agree with the words of N. Lavrychenko regarding three levels of the deployment of national identity concerning the formation of human certainty (biogenetic, socio-psychological, cultural-historical) [19, p. 286]. At the same time, nationality is considered more social, than biological phenomenon due to assimilation of a significant degree of value orientation depending on the environment. The result of such socialization as a manifestation of social competence is the formation of national identity of an individual.

\section{CONCLUSIONS}

Taking into consideration the abovementioned, we should state the following. All factors affecting the development of a society or functioning in it form a determinant of social development; they are 
phenomena of culture as a society, and every individual. They enable the systematic analysis of social phenomena in a multifactorial dimension, including the development of social competence.

Mentality is a determinant, a defining characteristic that ensures the adaptation of society members to changes in socio-economic, spiritual and cultural conditions; it demonstrates the vision of people of particular historical time, geographical area and social environment, a special psychological type of specific social formation.

The attention is drawn to mentality of a particular person - individual mentality, individual mental profile, which determines life scenario, personal values and stereotypes, perception of the world, the place of individual in it, public opinion and the laws of morality. Group mentality (civilization mentality, ethnic and nation mentality) is also in the focus of attention. Group (collective) mentality is presented as a manifestation of solidarity of people - primary subjects of consciousness. That is why mentality is a deep level of collective and individual consciousness of a person or a social group; it promotes a certain type of perception, thinking and action.

National mentality encompasses a system of ethnopsychological, ethnoideological, national, ideological dimensions of historical background; it is a synthesis link of manifestations of ethnic and national spirit.

Ethnic mentality is spiritual and cultural self-manifestation of members of ethnic communities in ethno-differentiating features, a way of perceiving world environment with the peculiarities of responding to its phenomena, depending on ethnic factors, norms and values, moods and forms of relationships.

Specific features of national mentality as an element of a complex methodological system ensure the objectivity of theoretical knowledge. The form of information existence is one of the main criteria for the structure of national mentality. Through it, mental content is transmitted, and it contributes to the awareness of the perception of the outside world.

National mentality of the Ukrainians of both positive and negative character is unique due to sociocultural factors, and its archetypal basis fuels the sources of national revival. In the context of the transformational processes of the modern Ukrainian society, taking into account its heterogeneous ethnic structure, we can assume that the chosen way of European integration can be realized on the basis of a deep level of collective and individual mentality, dialogue on religious and cultural theories, readiness to perceive innovative social ideas and norms within ethnic groups, and at the level of the Ukrainian nation.

The aforementioned conclusions do not cover all aspects of the outlined topic, and lay the basis for further study of determinants of the development of social competence; they can be considered a discussion on the issue of unity and contradictions of socio-cultural traditions and transformations.

\section{REFERENCES}

[1] Andruschenko V.P. Philosophical Dictionary of Social terms. Korwin, Kyiv-Kharkiv, 2002. (in Ukrainian)

[2] Budnyk O.B. Ethnopedagogy of Economic Education of Schoolchildren. Tipovit, Ivano-Frankivsk, 2005. (in Ukrainian)

[3] Chuprii L.V. National Security Policy of the Ukrainian State in the Humanitarian Sphere: Conceptual and Institutional Analysis. Publisher: Kozhukhovskyi I. I., Kyiv, 2015. Available at: http://er.nau.edu.ua:8080/handle/NAU/20073 (in Ukrainian)

[4] Doroshenko S. I. Socio-historical determinants of the traditional attitude of the French to politics in the era of the Ancient order. Ukrayinska Natsionalna Ideia: Realii ta Perspektyvy Rozvytku, 19 (2007), 11-19. (in Ukrainian)

[5] Dretske F. Explaining Behavior: Reasons in a World of Causes. MIT Press, Cambridge, MA, 1988. 
[6] Fodor J.A., Pylyshyn Z.W. Connectionism and cognitive architecture: A critical analysis. Cognition, 28 (1-2) (1988), 3-71. doi: 10.1016/0010-0277(88)90031-5

[7] Frolova O.V. Features study presentation etnicheskih stereotypes in the process of communication. Young Scientist, 1 (03) (2014), 171-175.

[8] Hubskyy E.F., Korableva H.V., Lutchenko V.A. (Eds.) Philosophical Encyclopedic Dictionary. YNFRA-M, Moscow, 2007. (in Russian)

[9] Yvyna A.A. (Ed.) Philosophy: An Encyclopedic Dictionary. Hardaryky, Moscow, 2004. (in Russian)

[10] Gurvitch G. Déterminismes sociaux et liberté humaine. Vers l'étude sociologique des cheminements de la liberté, 2-e éd. PUF, Paris, 1963. (in French)

[11] Gurvitch G. Problèmes de la sociologie générale. In: Traité de sociologie, Vol. 2, T. 1. PUF, Paris, 1958, 155-251. (in French)

[12] Honcharenko S.U. Ukrainian Pedagogical Encyclopedic Dictionary, 2 ed. Volyns'ki oberehy, Rivne, 2011.

[13] Hrabovskyi S. The Concept of Mentality in Social Sciences. Heneza, 1 (3) (1995), 8-13. (in Ukrainian)

[14] Hurevych A.Ya. On Crisis of Modern Historical Science. Voprosy istorii, 2-3 (1991), 21-35. (in Russian)

[15] Hurevych A.Ya. Lessons of Lucien Febvre. In: Febvre L. The Battles for the History. Nauka, 1991. (in Russian)

[16] Shynkaruk V.I. (Ed.) Encyclopedic Dictionary of Philosophy. Abrys, Kyiv, 2002. (in Ukrainian)

[17] Kriachko V.I. Sociodiagnostic Perspective of Ukrainian Mentality. NVP "Interservis", Kyiv, 2012. (in Ukrainian)

[18] Kulchytskyi O. Ukrainian world perception. In: Ukrainian Soul. Feniks, Kyiv, 1992, 48-65. (in Ukrainian)

[19] Lavrychenko N.M. Pedagogics of Socialization: European Outline. ViRA INSAYT, Kyiv, 2000. (in Ukrainian)

[20] Lebon H. Psychology of Crowds. Institute of Psychology of the RAS, KSP+, Moscow, 1998. (in Russian)

[21] Machulin L. Sociocultural determinants of urban culture in Slobozhanshchina region in XVII-XVIII centuries. Kyivske Muzykoznavstvo, 42 (2012), 33-39. Available at: http://glierinstitute.org/ukr/digests/042/5.pdf (in Ukrainian)

[22] Maevska L.M. Ethnic cultural up-bringing: views on the problem. Scientific Bulletin of Uzhhorod University. Series: Pedagogy. Social work, 8 (2005), 95-98. Available at: http://eprints.zu.edu.ua/4319/1/etnokul'turne_vykhovannya.pdf (in Ukrainian)

[23] Kachanova S., Kryzh V., Sokol P. Mentality as an Object of Socio-political Analysis. In: The Man in the Sphere of Humanitarian Cognition. Ukrayins'kyy Tsentr dukhovnoyi kul'tury, Kyiv, 1998. (in Ukrainian)

[24] Orban-Lembryk L.E. Socio-cultural and Ethnopsychological Peculiarities of Communication. Zbirnyk Naukovykh Prats: Filosofiya, Sotsiolohiya, Psykholohiya, 8 (1) (2003), 3-19. (in Ukrainian)

[25] Palamar A. The Third Ruin: Reflections on the Misery. Kots M.P., Kyiv-Kharkiv-Ternopil-New York, 1988. (in Ukrainian)

[26] Pidlasyi I. The Ideals of Ukrainian Education. Ridna Shkola, 4 (844) (2000), 6-13. (in Ukrainian)

[27] Pitt D. Mental Representation. Stanford Encyclopedia of Philosophy, 2000. Available at: https://plato.stanford.edu/entries/mental-representation/

[28] Podlasyi Y.P. Pedagogics: New Course. In 2 books. Book 1: Common Basics. Learning process. VLADOS, Moscow, 2003. (in Russian)

[29] Rassel Dzh. Sociocultural Approach. "VSD", Moscow, 2013. (in Russian)

[30] Romanenko Yu.V. Socialization of Individual: Metaprogramme and Psychotechnological Aspects. DUIKT, Kyiv, 2007. (in Ukrainian)

[31] Sandyuk L.A. Fundamentals of Cultural Studies. Tsentr Uchbovoi Literatury, Kyiv, 2012. (in Ukrainian)

[32] A study of sociocultural factors. Scientific Library named after V.N. Ignatov. Available at: http: //www.f-mx.ru/sociologiya_i_obshhestvoznanie/izuchenie_sociokulturnyx_faktorov.html (in Russian)

[33] Shmorhun O. New socio-economic system: from utopia to ... myth? Politolohichni chytannya, 3 (1992), 17-48. (in Ukrainian)

[34] Sorokyn P.A. Man. Civilization. Society. Polytyzdat, Moscow, 1992. (in Russian)

[35] Socio-cultural Approach to the Analysis of Society. Scientific Library named after V.N. Ignatov. Available at: http://www.f-mx.ru/sociologiya/sociokulturnyj_podxod_k_analizu.html (in Russian)

[36] Complak K. Human dignity: nature, content and prerequisites of its presence. Publichne parvo, 4 (8) (2012), 14-22. Available at: http: //www.yourfuture.org.ua/ua/pb/2012/8/Complak.pdf (in Ukrainian) 
[37] Pavlyuk S.P., Horyn H.Y., Kyrchiv R.F. (Eds.) Ukrainian Ethnography. Feniks, Lviv, 1994. (in Ukrainian)

[38] Varetska O.V. Development of Social Primary School Teacher's Competence in the System of Postgraduate Pedagogical Education. Kruhozir, Zaporizhzhia, 2015. (in Ukrainian)

[39] Volkov H.N. Ethnopedagogic. Akademyya, Moscow, 1999. (in Russian)

[40] Vyshnevskyi O. Modern Ukrainian Education. Pedagogical Essays. Lviv. obl. nauk.-metod. in-t osvity; Lviv. obl. ped. t-vo im. H. Vashchenka, Lviv, 1996. (in Ukrainian)

[41] Yakupova N. Nation of the New Millennium. Available at: http://vatandash.ufanet.ru (in Russian)

[42] Yevtukh V.B. Ethnicity: Encyclopedic Reference Book. Feniks, Kyiv, 2012. (in Ukrainian)

Address: Olena Varetska, Public Educational Institution "Zaporizhzhia Regional Institute of Post-Graduate Pedagogical Education" Zaporizhzhia Regional Council, 57-A, Nezalezhnoii Ukraiiny Str., Zaporizhzhia, 69035, Ukraine.

E-mail: olena_varetska@i.ua

Received: 19.11.2018; revised: 04.03.2019.

Варецька Олена. Колективні ментальності у системі соціокультурних детермінант розвитку соціальної компетентності особистості. Журнал Прикарпатського університету імені Василя Стефаника, 6 (1) (2019), 19-27.

У статті обгрунтовано актуальність розвитку соціальної компетентності особистості в умовах глобалізаційних змін, окреслено авторський погляд на вплив колективних ментальностей у системі соціокультурних детермінант, досліджено погляди науковців на сутність ментальності, ментальності особистості й групи, нації й етносу, висвітдено риси етнічних українців, природної мождивості об'єднання навколо національної ідеї.

Кдючові слова: соціальна компетентність, особистість, детермінанта, система, ментальність, колективні ментальності, етноментальність, національна ментальність. 